\title{
The Jordanian General Prosecutor Decision No. 1231 of 2008 over the Case of the Dutch Cartoons vs Prophet Muhammad (PBUH) Case
}

\author{
Khaled A. AlShakhanbeh ${ }^{1}$ \\ ${ }^{1}$ School of Law, Middle East University, Amman, Jordan \\ Correspondence: Khaled A. AlShakhanbeh, Assistant Professor in Commercial Law, School of Law, Middle East \\ University, Amman, Jordan. E-mail: khaled_h_2@hotmail.com
}

Received: January 24, 2017

Accepted: February 28, 2017

Online Published: November 29, 2017

doi:10.5539/jpl.v10n5p48

URL: https://doi.org/10.5539/jpl.v10n5p48

\begin{abstract}
In 2005, Dutch cartoonist Kurt Faster Gurt published sketches of Prophet Muhammad (PBUH) in the Jyllands-Posten newspaper as well as in PDF form via its website. The images depicted the Prophet (PBUH) and his companions in what Islamic countries around the world deemed as derogatory at best and blasphemous at worst. This article looks at the decision by the Jordanian General Prosecutor to put on trial Kurt Faster Gurt and his cartoonists in 2008, which opened the flood gates to numerous challenges to domestic cyber laws having international jurisdiction. From Yahoo to YouTube, the Jordanian decision set a precedent for what has become a new world of law and politics, whereby Internet content producers, no matter where in the world they appear, could be held accountable to domestic cybercrime laws. To explain the Jordanian approach, other legal cases are studied in which it is proven that the damage caused by some material available in the Internet may justify the indictment of their authors by national Courts regardless the defendant's nationality or place of residence. Such cases urge States to provide for themselves an adequate legal corpus to be able to cope with these cases and to be able to implement the Court's decisions.
\end{abstract}

Keywords: Dutch Cartoon, Prophet Muhammad (PBUH), internet law, Jordanian General Prosecutor

\section{Introduction}

The well-known scientist Stephen Hawkingssaid:'We are all now connected by the Internet, like neurons in a giant brain'.Therefore, if we are all connected by the Internet, and we all share its wonders and vices, it is also the case that users can be affected by its content. This was the main argument pursued by the Jordanian General Prosecutor in 2008, with regards to the Dutch cartoons depicting the Prophet (PBUH) in 2005. The case deserves to be investigated by the sheer fact of it being the first of its kind in the Islamic world. The message was clear: any online content deemed offensive to Islam would result in prosecution no matter where in the world such material was being produced. Its existence in cyber-space meant that it was available to anyone in the world through accessibility and availability.

The nature case was two-fold: on the one hand, the mere sketching of the Prophet contradicted Sharia Law. It was simplyun-Islamic, since the physical worship, or depiction of any religious icon is forbidden by Islam. It is essential that this fundamental pointbe taken under consideration when debating issues related to this case. Thus, the cartoons, as published online by Jyllands-Posten in 2005, disregarded the teachings of an entire religion under the umbrella of freedom of speech and democracy as on Dutch soil and the presumed right to free speech online. On the other hand, this case was prominent precisely because cyber-space does not belong to any one nation. Therefore, the Jordanian General Prosecutor's decision to bring to trial the Dutch cartoonist's online publication reverberated across the world. The question of why such images were created in the first place is a debate for another paper, but the cartoonists would have known, undoubtedly, that such images would be accessible to Muslims around the world. Additionally, the availability of these images online made it considerably difficult, if not impossible, to police. In order to claim some authority over the damages caused by the images, the Jordanian Court's reference to its domestic Internet crimes laws to prosecute and punish the Dutch cartoonists in Jordan raised questions about rights of Internet users as well as the creators of such materials. Arguably, it is held that the right to publish any content outweighs the emotional and psychological damage such content would cause to its audience. The Jordanian, and subsequent cases, contradict and challenge these rights through its domestic legal system. 
This research highlights the conflicts and complexities within domestic and international Internet laws, as well as providing evidence of cases where international jurisdiction has been applied and been successfully implemented. It seeks to examine what the requirements are for bringing to trial the producers of Internet content which may directly affect its audience. There are cultural differences at play, as well as where there may be a case for political leverage. The Yahoo! and YouTube cases are used to further investigate how the availability of content and where it is accessed can greatly influence a case. The Jordanian case also highlights the 'impact and effects' approach to understanding how it became a ground-breaking case.

\section{The Aspects of the Dutch Cartoons Case according to Internet Law}

\subsection{The Legal Complexity of Suing Authors of Blasphemy in the Internet}

First published in 2005 by the Danish newspaper,Jyllands-Posten, the images were published both in paper form and as a PDF on its website. ${ }^{1}$ These images were widely condemned by the Islamic world. They were perceived asoffensive to the Islamic religion, not only in their content, but in the very fact of its existence, given that creating images of the Prophet is not allowed in Islamic Sharia law. ${ }^{2}$ The issue that makes this case one of most interesting and controversial in relation to this thesis is that, although in creating these images the Dutch cartoonist's purpose may not expressly have been to offend Muslims, nor to flout Sharia Law, Kurt Faster Gurt's sketches had been viewed (via direct or indirect access to the Internet) by Muslims, leading to mass demonstrations and political implications. The offence was unforeseen in the eyes of the Dutch creators. And since this current research is about investigating aspects of Internet law in the Muslim world, the case is very pertinent to the question as to whether or not downloading culturally offending images constitutes an offence in law (for instance, in some countries downloading ambiguously naked pictures of young children does not amount to a crime, whilst in others, it is a criminal offence). Certainly making this cartoonist's work available for download to servers in Islamic countries, such as Jordan, would be seen to represent an Internet activity deemed illegal in those countries.

\subsection{The Jordanian's Court National Legal Apparatus to Judge an Offence Committed in the Internet}

Focusing specifically on Jordanian law, the cartoonist was accused of publishing work which depicted blasphemous images of the Prophet Muhammad (PBUH). ${ }^{3}$ In this case, the General Prosecutor of the Amman First Instance Court issued an order to the Dutch cartoonist, Kurt Faster Gurt (in addition to 19 other defendants), to appear before the Amman Court. The Prosecutor's decision, based on article 5 of the Criminal Code, was taken after these cartoons had been published on the Internet and had been deemed to have insulted the Islamic World in general, and ignored the religious rights of Jordanian citizens in particular, under Jordanian law.This brings us to the question of jurisdiction in this case: in order to claim jurisdiction of the Jordanian Courts over the named publications, the Jordanian prosecutor referred to Article 5 of the criminal procedure law: Articles 18, 19 and 20 of the International Convention on Civil and Political Rights, as well as to Article 38 of the Jordanian Electronic Transaction Law of 2000. According to the indictment, the defendants were considered punishable under Jordanian law for crimes based on Chapter One of Title Six of the Jordanian Criminal Code. ${ }^{4}$ The most important point in this case is that a Jordanian Court, by acting thus, was taking upon itself to extend its jurisdictional authority and to claim jurisdiction over crimes committed outside the country, in accordance with the material rules of its penal jurisdiction. ${ }^{5}$ In the event, the case was found to fall under the Amnesty Law No. 15 of 2011 and was closed; the rationale being that the complaint was in regard to a criminal offence (material damage) but did not contain a civil compensation claim for moral damage as a result of the defendants' crime. Even though this 2008 case in regard to static images did not include any claims of moral damage alongside material damage, a different case which did make such claims, No. 1171/2007, was filed in 2011 before the

\footnotetext{
${ }^{1}$ The Danish Newspaper "Jyllands-Posten", on September, $30^{\text {th }}, 2005$, published on page 3 of its culture section a PDF accessible article entitled "Muhammedsansight". This article contained cartoons images of the Prophet Muhammad (PBUH) and his companions. This action was deemed as insulting and offensive to those following Prophet Muhammad's Islamic teachings, which are that graven images should be avoided in relation to religious subjects.

${ }^{2}$ It is important to say here that a full reference for this article is provided in the interests of research transparency and accountability; however no direct link is provided since for the researcher to do so would to involve him in actions which countermand his religious beliefs. That is, whilst the source is provided for those who need to consult it, it should be noted that the researcher wishes to distance himself from the content of the sources and its images.

${ }^{3}$ The General Prosecutor order number 1231 of 2008.

${ }^{4}$ Charges included in the indictment were slandering prophets, dissemination of offensive publication and manuscripts, drawings that would offend the religious sentiments of Muslims, libel and slandering by publication, and abuse of the Prophet Muhammad (PBUH) by writing, drawing or fabricating images.

${ }^{5}$ The General Prosecutor order number 1231 of 2008.
} 
Amman First Instance Court. The case referred to the film "The Innocence of Islam" which contained derogatory images and references to the Prophet and his companions (PBUH), provoking similar outrage on the cartoons across the Muslim world ${ }^{7}$. In this latter case, based on film montages, the claimants included both material and moral damages in their complaint against the writer, publisher, producer and all actors in the film. Suffice to say, the initial 2008 case had given precedence to this subsequent case, opening the flood-gates to others that would be more detailed in the scope of the complaints.From a research point of view, the 2008 case is important in being the first case of its type to be put before a Court in the Islamic world. ${ }^{8}$ Although the case happened to be established in Jordan, by right of being seen to have affected Jordanian citizens; evidently, the impact of such a case was not restricted only to Jordanian Muslims but could be replicated in any Islamic country. Arguably, the Jordanian Court's decision to prosecute was based by implication on an assumption that any non-Jordanian Muslim would equally be affected by the defendant's publications.

\subsection{The Jordanian Court' Sperspective and Its Outcome}

What is equally important is that this case opened the door to further potential prosecution of any Internet publication made accessible to Jordan, and involving cyber activities that might be seen to violate Jordanian laws, as to include the amended Article 5 of the Penal Code and Article 38 of the Electronic Transaction Law. Also it cannot be ignored that the Jordanian action against the published cartoon images in the 2008 case was the first legal action of its type, after violent demonstrations had spread around the Islamic world. ${ }^{9}$ The position taken by Jordan in this case reverberated across the world but with the greatest impact in Islamic and Arab countries.However, it is important at this point to discuss the Court attitude in adopting the accessibility and availability approaches over this case, which also appears in the cited Jordanian cases. The Court stood by its position that the defendants' materials, being published on a website accessible and readable in Jordan, by any person who was able to download them from a server in Jordan, constituted a crime in relation to the rules of access and download. In taking this position, the General Prosecutor did not limit his judgement as only applicable locally to Jordan, but sought to support his position that this case was internationally relevant by referring to articles of the International Convention on Civil and Politics Rights as to the violation of human rights.However, the fundamental argument in these two approaches is simply that a Court may find jurisdiction present where a website is available and can be accessed in the Court foreign state. ${ }^{10}$

\section{Legal Precedence}

\subsection{The Similar Approach between the Jordanian and Frenchjudgement: The LICRA/UEFJ vs Yahoo France}

Generally speaking, this approach was most prevalent during the early stages of Internet development, when Courts were struggling to interpret conditions in the new virtual world and were discovering the difficulty of subjecting cyberspace to traditional jurisdiction rules. Thus, Courts adopted the access approach as a justification for establishing jurisdiction, where the defendant's website could be deemed to be accessible, or the Internet available, in a foreign country. ${ }^{11}$ To clarify, the availability of the Internet means that the plaintiff or a third party involved in a cyber-case may have access to the Internet, and that through this access the party will be able to engage with a defendant's website. ${ }^{12}$ In such cases, there is no difference between civil, commercial or criminal cases, as long as the merits and the cause arising from a defendant's Internet activity can be located by direct or indirect means on a specific website. Examples can clearly be seen in cases involving intellectual property infringement on the Internet, and libel or defamation cases in cyberspace. ${ }^{13}$ The claimants in this case had asked the Court to consider Internet cases subject to foreign jurisdiction that had applied these two jurisdiction approaches. One of the cases considered, pertained to a French Court of lawwas La LigueContre le

\footnotetext{
${ }^{6}$ A 74 minutes movie produced in America and broadcasted on www.youtube.com

${ }^{7}$ The General Prosecution Department, the General Prosecutor indictment decision No.7025 of 2012. Issued on the $28^{\text {th }}$ of April 2013 and the case currently is hearing by the Amman First Instance Court.

${ }^{8}$ Samson, Elizabeth. "Jordan Indicts 12 Europeans, Including Geert Wilders, for Demeaning Islam". Wall Street Journal Europe, September 10, 2008. Available at: <http://www.amnation.com/vfr/archives/011396.html $>$.

${ }^{9}$ As a consequence of publishing the Dutch cartoons against Prophet Muhammad (PBUH), huge demonstrations were spread in Arab and Islamic countries to refuse the said publications against the Prophet of Islam. The demonstrations mainly targeted Denmark and the Netherlands embassies in Islamic countries and they also reached American and other western embassies.

${ }^{10}$ Edwards, Lilian and Waelde, Charlotte.Law \& the Internet: Regulating Cyberspace (Hart Publishing, Oxford 1997). P 61-63.

${ }^{11}$ Arab, Cyber Law (Union of Arab Banks Publisher, Beirut 2001).p. 47.

${ }^{12}$ Inset System, Inc. v. Instruction Set, Inc. 937 F. Supp. 161 (D. Conn. 1996).And US v. Truesdale, 152 F. 3d 443 - CA 5 th Circuit 1998.

13 Fink, Benjamin and Wagner, Steven.'Personal Jurisdiction and the Internet' [2004] Law Journal Newsletters $<$ http://www.lawjournalnewsletters.com/issues/ljn_Internetlaw/2_10A/news/143491-1.html >.
} 
RacismeetL'Antisémitisme (LICRA) \&l'Union des EtudiantsJuifs de France (UEJF) v Yahoo! Inc\& Yahoo France. 2000. ${ }^{14}$ In this instance, LICRA \& UEJF filed a case before the Paris High Court against the Yahoo Company for selling memorabilia from the Nazi period (e.g. images, logos, etc.) by means of Internet auction. The claimants argued that Yahoo's Internet action contravened the French Criminal Code under which they lived. ${ }^{15}$ In this case, the French judiciary awarded jurisdiction to the French Courts, even though Yahoo France was accepted as a branch of the central server in the USA. Even if this were so, the main criterion for jurisdiction was that the broadcasting was accessible in France and to French people. ${ }^{16}$ The Court clarified the position in deeming that the auction of Nazi memorabilia had the capacity to affect people from all countries, including French citizens but specifically in relation to the rights of its own citizens, the fact of including offending articles in the auction could be taken to be an offense against French Criminal Law. Moreover, the French Court claimed jurisdictional authority on the basis that the website was accessible in France and targeted French citizens, in that it used the French language in its advertisements on the website. Yahoo was also found to be using French lawyers for its administration and to own $70 \%$ of the French Company shares (Yahoo! France).In May $22^{\text {nd }}$, 2000, the Courtwho had been awarded jurisdiction ordered that within a period of three months Yahoo! should remove the memorabilia and any related materials from its website, and take measures to prevent their auction sites from being accessible in France. Failure to comply after the grace period of three months would incur a fine to the company of 100.000 Francs per day. Yahoo! responded to the Court by arguing that it would be unable to effectuate the required technical measures in a period shorter than six months and that it would incur costs of over half a million US dollars in making the changes. Nevertheless, the Court rejected the Yahoo! defence and referred to the opinion of French experts appointed to this case, whose findings were that the company had the capacity to suppress more than $70 \%$ of the offending domain names immediately, and that the remaining $30 \%$ could be resolved by taking certain measures such as requiring users of a website to declare their nationality before accessing the website. In this case, if users declared their nationality as French, then access to the contested web materials would be denied to them.The Yahoo! Company decided not to appeal the French judgment in France, but to prevent the enforcement of the French Court judgement in America. Thus, on January $10^{\text {th }}, 2001$, Yahoo! filed a case before the US District Court of the Northern District of California in San Jose. In its requests, Yahoo! asked the Court to rule that the French judgement was not applicable in the US. The Court accepted this request and announced that the judgement was not applicable in the US, as inconsistent with the American Constitution and laws related to freedom of expression. Nevertheless, on August $23^{\text {rd }}$, 2004, LICRA and UEJF appealed the Court decision before the US Court of Appeal of the $9^{\text {th }}$ Circuit. In this instance, the Court reversed the District Court's judgement, and found that that Court did not have personal jurisdiction over the appellants LICRA and UEJF.Although Yahoo! subsequently did carry out the required measures to prevent access to the offending websites, it is useful to speculate as to why Yahoo had not initially been prepared to accept these procedures as a response to the French order. It was only after pressure from US based groups and communities, such as Jewish-American organisations, that the company was ready to comply. ${ }^{17}$ From this research point of view, the import of this case is that it illustrates that countries can directly control their own national Internet Services Providers (ISPs) but have no direct control over foreign ISPs. The Yahoo! case exemplifies the kinds of difficulties that may emerge from attempts to apply domestic rules over foreign activities, in cases where these rules contravene or otherwise fall foul of other countries' laws. This is clearly demonstrated by the case of the Yahoo! auction of Nazi memorabilia, an action illegal in France but lawful

\footnotetext{
${ }^{14}$ LICRA \& UEJF v Yahoo! Inc\& Yahoo France.

${ }^{15}$ See Article R645-1 of the French Criminal Code:

"Article R645-1 of the French Criminal Code prohibits to "wear or exhibit" in public uniforms, insignias and emblems which "recall those used" by

- an organisation declared illegal in application of Art. 9 of the Nuremberg Statute, or by

- a person found guilty of crimes against humanity as defined by Arts. L211-1 to L212-3 or by the Law № 64-1326 of 1964-12-26.

Display is allowed for the purposes of films, theatrical productions and historical exhibitions.

The penalty is a 5 th class fine (up to 1,500 EUR), to which can be added one or more complementary penalties among:

- withdrawal of the right to possess or hold any regulated weapon for up to three years;

- confiscation of one or more regulated weapon either possessed by the convict or to which he has a free access;

- confiscation of the objects concerned;

- from 20 to 120 hours of community service".

${ }^{16}$ Gray, Tricia. 'Minimum Contact in Cyberspace: The Classic Jurisdiction Analysis in a New Setting' (2002) 1 JHTL, pp. 85-100.

${ }^{17}$ Perritt, Henry. 'Dispute Resolution in Cyberspace: Demand for New Forms of ADR' (2000) 15 Ohio State Journal on Dispute Resolution.
} 
elsewhere, in this case under US law. ${ }^{18}$ Considering the Yahoo! case from the Jordanian perspective, we could argue that in a parallel case, Jordan did not accept the Dutch defendant's argument that the newspaper website was in Denmark, but rather argued that so long as the website was accessible from Jordan, the defendant's activity was punishable under Jordanian laws. Ipso facto, the Jordanian Court would have the jurisdictional right to hear the dispute, and future disputes arising under similar conditions.

\subsection{The Egyptian Standpoint on a Blasphemous Film against Islam}

Another precedence case presented here illustrates the application of domestic jurisdiction rules over a website broadcasting criminal activities against a country's laws, in this case Egypt. The case concerns an Egyptian judgement against Youtube.com. In 2013, an Egyptian judge, HassounaTawfiq, sent an order to the Egyptian government to block the website www.youtube.com for 30 days, after the website was found to be sharing a 14 minute trailer for a film named "Innocence of Islam". It was believed in Egypt that this trailer was insulting the Prophet Muhammad (PBUH) and the Islamic Creed, ${ }^{19}$ citing similar condemnation as the Dutch-Jordanian case. As an aside here, it is useful to say that this judgement was not the first order of its type: several Courts in Egypt had previously issued such judgements against Internet websites which were believed to contain episodes or feature films seeming to insult to Islamic beliefs. Later films also came into the same category. For instance, in 2007, an Egyptian Court ordered a ban on several human rights websites because of the contents of these websites were considered to contravene Egyptian laws. However, in this case the judgement was rejected by the Administrative Court in Egypt, since the Court did not accept the government's defence and considered its actions as a political tactic in attempting to control and fight freedom of speech for the Egyptian revolution.A similar action was brought about in 2011, when as a consequence of disturbances arising from the Egyptian Revolution, the former Egyptian president (Hosni Mubarak) ordered the blocking of hundreds of human rights and social forums websites as a means of limiting Egyptian protesters' capacity to use the Internet to broadcast the country's news abroad. ${ }^{20}$ To return to the 2013 case of the "Innocence of Islam", the Court's judgement was based on the argument that the film contained "blasphemy and insults to religious messengers and prophets", and as such, constituted a crime against the Egyptian 2012 Constitution. The Court rejected the position held by some human rights groups that the Court had no jurisdictional authority over this case, on the grounds that the film contained transparent acts and words which were considered a crime punishable under Egyptian laws. With reference to this research, this case left a major impact on the life of Egyptian citizens in regard to the use of media via the Internet. The ruling of the Court was based on the jurisdictional principle that the website YouTube.com - was accessible in Egypt and that the person who made the film held Egyptian nationality, regardless of the film's being broadcast from a place in the US.

\section{The Effects and Ham Approach: Cases That back up Jordan Court's Perspective}

In addition to the two jurisdiction approaches above, the impact and effects approaches has also been recognised as valid for the Jordanian case cited above. It underpins the findings of this research that cases where the place of effects has been combined with the place of harm have resulted in damaging consequences to one of the case parties. For instance, in civil cases, breaching a contract is considered an effect whereas failing to deliver a product can be considered as harm done. Also in criminal cases, the effect in a cyber-defamation case can be argued. For example, the damage may have been to a defamed person's reputation, while the harm done can be deemed as losing public trust or business interests. ${ }^{21}$ The effects and harm approach is derived from the objective territorial theory, a theory which builds on the idea that an activity may take place under the jurisdiction of a particular region, but also that the impact of this activity may extend beyond the forum jurisdiction to that of another country or countries. ${ }^{22}$

\subsection{The Case Olez Zezev vs. the Bloomberg Company: The US Approach to Fight Hacking of Personal Information}

Other Jordanian and Arab researchers and literatures have also discussed the Dutch case in terms of extending domestic legislation over cyber activities and referred to the two cases below to justify the Jordanian attitude in

\footnotetext{
${ }^{18}$ Kissinger, Henry. 'The Pitfalls of Universal Jurisdiction' (Aug 2001) an article adapted from his latest book: Does America Need a Foreign Policy? Toward a Diplomacy for the 21 st Century. $<$ http://www.icai-online.org/xp_resources/the_pitfalls_of_uj.pdf $>$.

19 The Guardian Newspaper: " Egypt Court bans YouTube over Innocence of Islam trailer" http://www.guardian.co.uk/world/2013/feb/10/egypt-Court-bans-youtube-muslims

${ }^{20}$ Ibid.

${ }^{21}$ BBC News, UK. 'Online defamation cases in England and Wales 'double' [2011] <http://www.bbc.co.uk/news/uk-14684620>

${ }^{22}$ Wilske, Stephan and Schiller, Teresa. 'International jurisdiction in Cyberspace: which states may regulate the cyberspace?’ [1999] $<$ http://www.law.indiana.edu/fclj/pubs/v50/no1/wilske.html $>$.
} 
claiming jurisdiction and prosecuting the Dutch defendants in Jordan.A well-known case which serves to illustrate the obstacles that may arise when internal domestic laws are applied over externally committed cyber activities is that of OlezZezevvs. the Bloomberg Company in America. In this case, there was an attempt to apply US domestic laws outside of American territories in the instance of a cybercrime. In February 2000, an individual named Zezev, from Kazakhstan, hacked into the Bloomberg company website and, using advanced hacking programmes, copied the company's account files and other secret documents related to the company's operations such as customer data. Zezev then used the nick name "Elias Alex" to send an email, including attachments of the hacked information, back to the company as an attempt at blackmail. Zezev threatened to publish the information if $\$ 200,000$ was not transferred to his bank account. The company's dilemma was that public disclosure of the information would be a risk to the company's reputation and would potentially destroy the trust of its customers. Bloomberg requested the help of the American Federal Bureau of Investigation (FBI), which directed the company to send an email to Zezev saying that to get the money he would have to meet Maikel Bloomberg in the UK. The FBI arranged with the British General Prosecutor Office to arrest Zezev, so that when he came to Britain and started explaining how he had hacked the company's website, the British police arrested him and surrendered him to the FBI. ${ }^{23}$ This case is of interest in terms of the current research, in that the American laws were indeed deemed to be extendable outside of American territories, and that the Court based its judgement in accordance with personal jurisdiction rules aiming to protect the interests of US citizens. Even though the defendant in this case was arrested in UK, and was not of American nationality, the US Court considered his cyber activity to be a crime impacting upon American territory.

\subsection{The Dow Jones vs Gutnick Case: The Australian Approach to Punish Defamation}

The second case cited in Jordanian research literature is the Internet defamation case of Dow Jones and Gutnick before the Australian High Court in 2002. ${ }^{24}$ This case illustrates the application of territorial and personal jurisdiction rules over Internet defamation cases. In October $30^{\text {th }}, 2000$, Dow Jones published an article entitled "Unholy Gains" in a New Jersey website called Barron's Online. This article contained several references to the respondent Joseph Gutnick, who was living in Victoria, Australia. Gutnick argued that as the article had defamed him, he had the right to prosecute Jones in Victoria, Australia, as his place of residence and as the place where the defamed article had left its effects.The High Court accepted Gutnick's argument and explained that Australian plaintiffs in Internet defamation cases have the right to sue their opponent defendants regardless of their location. The Court also decided that the defamation would have taken place at the time when a third party had read the publication, rather than at the time of publishing. In 2004 Dow Jones settled the case and paid Gutnick $\$ 580,000$ for both fees and compensation. ${ }^{25}$ The implication of this case is relevant for this research as the Court awarded jurisdictional authority over the Internet activity in accordance with the principle of the defamed person's domicile and nationality. The Court also referred to the effect and harm approaches in awarding the Australian Court the right of jurisdiction, and considered the time when the defamed information was readable by a third party as the time at which the crime occurred, rather than at the time of publishing the information.

A fundamental principle arising from this case can be agreed upon: the damage to reputation can be argued as occurring at the point when defamatory information becomes public, in so far as the damage may not be restricted only to the fact of notifying the defamed person of the information having been published. It is also argued that, following this principle, the right of jurisdiction in the above case was correctly given to the Court presiding in the place where most of the damage occurred.Returning once more to the Dutch case, it also serves to highlight a major issue in regard to international treaties and agreements. The issue specifically in this case was that Jordan had no surrender agreement with either Denmark or the Netherlands, as a consequence of which Jordan was powerless to order either country to surrender the defendants for prosecution before the Jordanian Courts. This was the outcome even though the Court had issued a final decision to punish the defendants for what were deemed as cybercrimes under Jordanian law. In order to overcome the legal obstacle constituted by lack of a surrender agreement, other Muslim lawyers argued that the Dutch defendants should be sued before their own country's Courts, or those of another country that had jurisdictional power to punish Dutch defendants, such as those in the UK.Currently, in terms of international agreements as to what constitutes a crime in Internetlaw, this case illustrates an important cultural and national divide as to what constitutes a crime locally or internationally. It also gives rise to the question as to whether prosecution in such contexts can lead to any

\footnotetext{
${ }^{23}$ OlezZezevvs the Bloomberg Company. Found in Alsaeid, Maher. Internet and E-Contract in Arab Word. Cairo University, P 900-917.

${ }^{24}$ Dow Jones and Company Inc v Gutnick (2002) HCA 56; 210 CLR 575; 194 ALR 433; 77 ALJR 255.

${ }^{25}$ Dow Jones and Company Inc v Gutnick (2002) HCA 56; 210 CLR 575; 194 ALR 433; 77 ALJR 255.
} 
satisfactory resolution. In this specific case, it could be seen as unprofitable to sue the defendants in Danish or Dutch Courts, given that in those countries the defendants' publications (the cartoons) were lawful under Danish and Dutch law, mainly in regard to freedom of speech and the right to individual expression. It is too early to say how such cultural differences, as to what constitutes freedom of speech, and what constitute a threat to citizen rights, can be resolved inInternet law.In the meantime, it is useful to reflect that in this particular case, even if non-suit could be pursued leading to claimant's benefit, the Jordanian Court stood by its decision to prosecute, and to claim extended jurisdiction of its rights in regard to the defendants' crimes as identified under Sharia law. That is, the General Prosecutor stood by his judgement that the crime was an offence against the Islamic creed of Jordanian citizens and as such, was subject to the targeting and damage jurisdiction tests used in Jordanian law. To contextualise this within the current research perspective, it could be said that a precedent had been set in Jordanian law, in that the Prosecutor General did not limit his judgement to the country's domestic legislation, but was ready to extend it by referring to an International convention. It cannot be ignored that the jurisdiction tests or approaches used by the Jordanian Courts in this case were identical to those national jurisdiction principles espoused by other countries with more advanced legal systems, such as the USA and the UK. The point here is that from a legal perspective, the Jordanian Court's position was that it was legally qualified to prosecute the Dutch and Danish defendants in Jordan, regardless of the fact that the defendants' publications were considered lawful in their own countries. Moreover, this position and argument could be replicated for similar cases that might be conducted in countries other than Jordan.Finally, it could be said that this type of case has set a precedent not confined to static images but to other media available via the Internet, as illustrated by the 2011 case brought by the Jordanian Courts against the makers of the film "The Innocence of Islam". In this case the claimant was able to refer not only to the existing laws as mentioned above, but also to the new Jordanian Information Cyber Crime Law of 2010. The drafting of this law, to deal with cybercrimes, was directly influenced by the outcome of the Dutch cartoons case. This reflects the reality that precedent cases do not only lead to future changes in jurisdiction, but also in the way that new laws are made.

\section{Conclusion}

The law governing Internet access and content is, undoubtedly, a minefield. Contentious material can cause international disputes resulting in far-reaching implications. Cyber-space has shown itself to be ungovernable, elusive and unstoppable, so much so that the rule of law has faced its greatest obstacles and challenges from 'What is offensive content?' to 'Who has the greater right to be protected, the producer or the audience?' and so forth. The Dutch cartoons brought to light, once again, the vast cultural and political divide between Islamic countries and the rest of the world. The Jordanian decision to prosecute and punish foreign producers of blasphemous work; the content of which being available in virtual reality for the entire planet to access, made one thing absolutely clear: Islamic countries will exercise their rights to international jurisdiction in order to protect their citizens from offensive material. What is deemed offensive in one country and not in another is currently being debated; nevertheless, depicting the Prophet (PBUH) in any characterisation is a crime and punishable in all Islamic nations. Thus, this research has sought to investigate how domestic cyber laws can be applied across international borders. Evidently, the Jordanian General Prosecutor's attempt to gain international jurisdiction was not an easy task. There was not any political leverage such as a surrender agreement, as seen in the Zezev case. Jordanian laws dealing with such Internet crimes was in its infancy in dealing with such controversial material, and subsequently, seeking to prosecute foreign nationals on Jordanian law when compared to the supreme legal systems of the US and the UK. We have seen how political and financial pressure has impacted law, such as the Yahoo! and Dow Jones cases. What is apparent here is that Internet users are greatly affected by controversial content, and it is one outcome which is proving to be indisputable. French nationals demonstrated outrage at Yahoo!'s auction sites, and individuals such as Joseph Gutnick's defamation case reveal how effect and harm approaches have been applied to winning cases. Despite numerous obstacles, the Jordanian law Courts have maintained their fight for what they see as an injustice towards the Prophet (PBHU) and to the Islamic world. This pursuit of foreign nationals for punishment, who created their work in secular and liberal states, catapulted the Islamic world into the limelight as being neither tolerant nor respectful of rights to individual expression (a point which is still being debated, and resolutions being sought in order to justify the on-going battle for what constitutes a cyber-crime). The Jordanian Information Cyber Crime Law of 2010 is attributed to the outcome of the Dutch case of 2008. To suggest that the 2008 set a precedent for the rest of the world in pursuing international jurisdiction is an understatement. New laws are being drafted to deal with new threats and at the same time the legality of whoever has jurisdiction over a world that is both virtual and real continues to be investigated. 


\section{References}

Arab, Cyber Law. (Union of Arab Banks Publisher, Beirut 2001).

BBC News, UK. 'Online defamation cases in England and Wales 'double'. (2011). Retrieved from http://www.bbc.co.uk/news/uk-14684620

Dow Jones and Company Inc v Gutnick. (2002). HCA 56; 210 CLR 575; 194 ALR 433; 77 ALJR 255.

Edwards, L., \& Waelde, C. (1997). Law \& the Interne: Regulating Cyberspace. Hart Publishing, Oxford.

Fink, B., \& Wagner, S. (2004). Personal Jurisdiction and the Internet. Law Journal Newsletters. Retrieved from http://www.lawjournalnewsletters.com/issues/ljn_Internetlaw/2_10A/news/143491-1.html

Gray, T. (2002). Minimum Contact in Cyberspace: The Classic Jurisdiction Analysis in a New Setting. 1 JHTL.

Inset System, Inc. v. Instruction Set, Inc. 937 F. Supp. 161 (D. Conn. 1996).And US v. Truesdale, 152 F. 3 d 443 CA 5th Circuit 1998.

Jordan General Prosecutor Order number 1231, 2008.

Kissinger, H. (2001, August). The Pitfalls of Universal Jurisdiction. an article adapted from his latest book: Does America Need a Foreign Policy? Toward a Diplomacy for the 21st Century. Retrieved from http://www.icai-online.org/xp_resources/the_pitfalls_of_uj.pdf

LICRA \& UEJF v Yahoo! Inc\& Yahoo France.

OlezZezevvs the Bloomberg Company. Found in Alsaeid, Maher. Internet and E-Contract in Arab Word. Cairo University.

Perritt, H. (2000). Dispute Resolution in Cyberspace: Demand for New Forms of ADR. 15 Ohio State Journal on Dispute Resolution.

Samson, E. (2008). Jordan Indicts 12 Europeans, Including Geert Wilders, for Demaning Islam. Wall Street Journal Europe. Retrieved from http://www.amnation.com/vfr/archives/011396.html

The Danish Newspaper, 2005.

The General Prosecution Department, the General Prosecutor indictment decision No.7025 of 2012. Issued on the $28^{\text {th }}$ of April 2013 and the case currently is hearing by the Amman First Instance Court.

The Guardian Newspaper: EgyptCourt bans YouTube over Innocence of Islam trailer. Retrieved from http://www.guardian.co.uk/world/2013/feb/10/egypt-Court-bans-youtube-muslims

Wilske, S., \& Schiller, T. (1999). International jurisdiction in Cyberspace: which states may regulate the cyberspace? Retrieved from http://www.law.indiana.edu/fclj/pubs/v50/no1/wilske.html

\section{Copyrights}

Copyright for this article is retained by the author(s), with first publication rights granted to the journal.

This is an open-access article distributed under the terms and conditions of the Creative Commons Attribution license (http://creativecommons.org/licenses/by/4.0/). 